\title{
JUKMAS
}

\section{Perilaku Hidup Bersih Sehat (Phbs) Terkait Menyusui Pada Ibu Yang Diduga Covid/Terinfeksi Virus Covid 19 Tahun 2020}

\author{
Fitria Sari, Yuna Trisuci Aprillia, Endang Siti Mawarni \\ Fakultas IImu Kesehatan Universitas Respati Indonesia \\ Jl. Bambu Apus 1 No. 3 Cipayung Jakarta Timur 13890 \\ Email : fitria_sari@urindo.ac.id
}

\begin{abstract}
Abstrak
ASI adalah makanan terbaik untuk bayi. Kandungan ASI sangat cocok untuk menunjang tumbuh kembang dan menjaga imunitas tubuh. Namun saat pandemi Covid 19 ini, banyak ibu yang khawatir dalam pemberian ASI ke bayinya. Salah satu yang menjadi kekhawatiran adalah penularan bisa terjadi pada saat memberi susu lewat ASI. Terlebih jika sang ibu terduga atau bahkan positif terinfeksi Covid-19. Sedangkan pada faktanya Virus ini tidak menular melalui ASI ibu yang positif Covid 19. Tujuan penelitian ini adalah untuk mengetahui hubungan antara perilaku hidup bersih dan sehat (PHBS) terkait menyusui dengan ibu yang diduga covid/terinfeksi covid 19. Penelitian mengggunakan rancangan "Cross Sectional". Populasi penelitian ini adalah seluruh ibu menyusui yang bersedia mengisi kuesioner yang akan diedarkan melalui sosial media sebanyak 152 responden. Hasil analisa univariat, responden yang berperilaku hidup bersih sehat sebesar $59,2 \%$, yang mengalami gejala covid sebesar $15,1 \%$, yang positif/diduga covid sebesar $1,3 \%$, dan yang pernah kontak langsung dengan penderita covid sebesar 10,5\%. Sedangkan pada hasil bivariat menunjukkan dari 3 variabel yang diteliti, tidak ada variabel yang berhubungan dengan PHBS yaitu ibu yang memiliki gejala sakit $(p=0,058)$, ibu yang positif/diduga covid $19(p=0,349)$ dan ibu yang pernah kontak langsung dengan penderita covid $19(p=0,276)$. Saran dari penelitian ini adalah perlu adanya edukasi bahwa ibu yang memiliki gejala sakit, positif atau diduga terinfeksi Covid 19 harus tetap menyusui bayinya dengan menerapkan PHBS. Hal ini untuk meningkatkan kelangsungan hidup bayi baru lahir, kesehatan dan perkembangan bayi dalam waktu dekat dan jangka panjang.
\end{abstract}

Kata kunci : PHBS, ibu menyusui, covid-19, pandemi

\begin{abstract}
Breast milk is the best food for babies. The content of breast milk is very suitable to support growth and development and maintain body immunity. However, during the Covid 19 pandemic, many mothers were worried about breastfeeding their babies. One of the concerns is that transmission can occur when giving milk through breast milk. Especially if the mother is suspected or even positively infected with Covid-19. Whereas in fact this virus is not transmitted through breast milk positive for Covid 19. The purpose of this study was to determine the relationship between clean and healthy living habits (PHBS) related to breastfeeding and mothers suspected of being covid / infected with covid 19. The study used a "Cross Sectional" design. . The population of this study were all breastfeeding mothers who were willing to fill out a questionnaire that would be circulated through social media as many as 152 respondents. The results of the univariate analysis showed that respondents who had a clean and healthy lifestyle were 59.2\%, those who experienced Covid symptoms were $15.1 \%$, those who were positive / suspected of Covid were $1.3 \%$, and those who had direct contact
\end{abstract}

http://ejournal.urindo.ac.id/index.php/jukmas

Article History :

Submitted 26 Nopember 2020, Accepted 28 April 2021, Published 30 April 2021 
with Covid sufferers were $10.5 \%$. Meanwhile, the bivariate results showed that of the 3 variables studied, there were no variables related to PHBS, namely mothers who had symptoms of illness $(p=0.058)$, mothers who were positive / suspected of being Covid $19(p=$ $0.349)$ and mothers who had direct contact with patients. covid $19(p=0.276)$. The suggestion from this study is that there is a need for education that mothers who have symptoms of illness, are positive or are suspected of being infected with Covid 19 must continue to breastfeed their babies by applying PHBS. This is to improve the survival of the newborn, the health and development of the baby in the near and long term.

Keywords: PHBS, breastfeeding mothers, covid-19, pandemic

\section{PENDAHULUAN}

Ada perbedaan mendasar perubahan lingkungan dan fisiologis janin yang ada di dalam kandungan dengan ketika bayi sudah dilahirkan. Beberapa perubahan yang drastis adalah upaya bayi mendapatkan nutrisi makanan dan cara mengeksresikannya. Janin ketika di dalam kandungan mengambil nutrisi makanan melalui plasenta.. Sedangan ketika lahir, bayi memasukan makanan lewat mulutnya. Berbagai penelitian mengatakan ASI adalah makanan terbaik untuk bayi. Kandungan ASI sangat cocok untuk menunjang tumbuh kembang dan menjaga imunitas tubuh [1].

Namun saat pandemi Covid 19 ini, banyak ibu yang khawatir dalam pemberian ASI ke bayinya [2]. Pada 11 Maret 2020, Organisasi Kesehatan Dunia (WHO) menyatakan penyakit virus korona baru 2019 (COVID-19) sebagai penyakit menular dengan lebih dari satu juta kasus yang dikonfirmasi [3]. Dampak kesehatan dari sindrom pernapasan akut yang parahcoronavirus-2 (SARS) -CoV-2) menjangkau semua kelompok umur termasuk ibu hamil. Bagi ibu dan bayinya yang baru lahir, pemberian ASI selama pandemi ini memerlukan perhatian khusus karena implikasi kesehatan jangka pendek dan jangka panjangnya [4].

Di salah satu Kecamatan Kabupaten Nganjuk Jawa Timur menyebutkkan bahwa persentase balita usia 6-24 bulan yang tidak pernah mengkonsumsi ASI masih tinggi pada masa pandemi yaitu 23\% [5]. Salah satu yang menjadi kekhawatiran adalah penularan bisa terjadi pada saat memberi susu lewat ASI. Terlebih jika sang ibu terduga atau bahkan positif terinfeksi Covid-19. Sedangkan pada faktanya Virus Covid 19 hingga saat ini belum terdeteksi pada ASI dari ibu yang positif atau diduga terinfeksi Covid 19 [6].

Pembatasan sosial atau Sosial Distancing sudah menimbulkan stress bagi orang kebanyakan. Rekomendasi Sosial Distancing ibu pada bayinya berbeda dengan rekomendasi untuk populasi 
umum. Anak anak beresiko lebih rendah terinfeksi Covid 19. Manfaat menyusui lebih besar daripada potensi risiko ketularan virus Covid 19 [7].

Jumlah kasus positif Covid-19 di Indonesia dengan total jumlah mencapai 14.749 orang. Pasien yang sembuh 3.063 kasus dan yang meninggal dunia sebesar 1.007 kasus kematian. Sebagian besar pasien Positif Covid 19 di Indonesia berada di usia produktif, termasuk ibu menyusui. Sekitar 54\% berada pada kelompok umur 30 sampai dengan 59 tahun. Sementara itu $16 \%$ pasien positif lain berada di usia 60-79 tahun, sekitar $15 \%$ berada di usia 15-29 tahun, di atas 80 tahun 1\% dan balita sebesar $0,6 \%$. [8]

Rekomendasi Perilaku Hidup Bersih dan Sehat (PHBS) juga penting diterapkan. PHBS adalah kumpulan perilaku yang dapat menunjang kesehatan baik untuk dirinya, keluarga dan masyarakat [9].

Dalam masa pandemi ini, rekomendasi perilaku hidup bersih dan sehat bagi ibu menyusui adalah mencuci tangan sesering mungkin dengan sabun dan air atau menggunakan hand sanitizer/rub berbasis alkohol, terutama sebelum memegang bayinya, menggunakan masker medis saat menyusui, bersin atau batuk dengan menggunakan tisu dan mendesinfektan secara teratur permukaan benda di sekeliling [6].

\section{METODE PENELITIAN}

Penelitian ini menggunakan rancangan Cross Sectional. Penelitian ini dilakukan di seluruh Indonesia pada Bulan Juni sampai Agustus 2020.

Populasi dan sampel pada penelitian ini adalah seluruh ibu menyusui yang bersedia mengisi kuesioner yang akan diedarkan melalui sosial media.

Populasi dan sample menggunakan rumus Slovin

Minimal sampel

Populasi : WUS Indonesia $2019=$ 71.149 .900

$$
\mathrm{n}=\mathrm{N} / 1+\mathrm{Ne}^{2}
$$$$
=71 \cdot 149.900 / 1+\left(71 \cdot 149.900 \times 0,05^{2}\right)
$$$$
=71.149 .900 / 177.875,75
$$

$=399,99=400$ sample

Estimasi $\pm 10 \%$ jadi 440 sample

Presentase terpenuhinya jumlah sampel dari sampel minimal adalah sebesar 152 responden (38\%).

Dengan alasan :

(1) Tidak semua ibu bersedia mengisi kuesioner karena tidak ada kompensasi yang diberikan dari peneliti

(2) Ada responden yang takut mengisi karena terkait data penderita Covid 19 atau bukan

(3) Ibu merasa sibuk dan tidak sempat mengisi kuesioner 
Data penelitian menggunakan data primer menggunakan Kuesioner dengan G Form. Pengambilan data dilakukan secara online melalui email, whatsapp group, facebook dan media sosial lainnya. Analisis data yang digunakan yaitu analisis univariat dan bivariat. Variabel dependennya yaitu perilaku hidup bersih dan sehat. Sedangkan variabel independennya yaitu gejala pada ibu menyusui, ibu yang positif/diduga covid 19 dan ibu pernah kontak langsung dengan penderita covid 19.

\section{HASIL DAN PEMBAHASAN}

Tabel 1. Distribusi frekuensi perilaku hidup bersih dan sehat (PHBS)

\begin{tabular}{lcc}
\hline PHBS & $\begin{array}{c}\text { Frekue } \\
\text { nsi (n) }\end{array}$ & $\begin{array}{c}\text { Persent } \\
\text { ase (\%) }\end{array}$ \\
\hline Ya & 90 & 59,2 \\
Tidak & 62 & 40,8 \\
\hline TOTAL & $\mathbf{1 5 2}$ & $\mathbf{1 0 0 , 0}$ \\
\hline
\end{tabular}

Berdasarkan tabel 1. dapat diketahui bahwa dari 152 ibu menyusui, ibu yang berperilaku bersih dan sehat sebanyak 90 orang $(59,2 \%)$ dan yang tidak berperilaku bersih dan sehat sebanyak 62 orang $(40,8 \%)$.

Rekomendasi perilaku hidup bersih dan sehat bagi ibu menyusui yang positif atau diduga terinfeksi Covid 19. Pertama, mencuci tangan dengan sabun dan air mengalir atau handsanitizer sebelum memegang bayi. Kedua, menggunakan masker medis saat menyusui. Penting sekali untuk mengganti masker segera setelah masker terasa lembab. Ketiga, tutup mulut dengan tisu ketika batuk atau bersin dan langsung mencuci tangan dengan sabun dan air mengalir. Keempat, mendesinfektan seluruh permukaan ruangan secara teratur. [8]

Tabel 2. Distribusi frekuensi gejala pada ibu menyusui

\begin{tabular}{lcc}
\hline \multicolumn{1}{c}{ Gejala } & $\begin{array}{c}\text { Frekuensi } \\
\text { (n) }\end{array}$ & $\begin{array}{c}\text { Persentase } \\
\text { (\%) }\end{array}$ \\
\hline $\begin{array}{l}\text { Tidak ada } \\
\text { gejala } \\
\text { Ada gejala }\end{array}$ & 129 & 84,9 \\
\hline \multicolumn{1}{c}{ TOTAL } & $\mathbf{1 5 2}$ & 15,1 \\
\hline \multicolumn{2}{c}{ Rerdasarkan tabel 2 } & dapat \\
\hline
\end{tabular}
bahwa dari 152 ibu menyusui berdasarkan gejala sakit. Ada sebanyak 129 orang $(84,9 \%)$ yang tidak memiliki gejala sakit dan 23 orang $(15,1 \%)$ memiliki gejala sakit.

Tabel 3. Distribusi frekuensi positif/diduga covid

\begin{tabular}{|c|c|c|}
\hline $\begin{array}{c}\text { Positif/diduga } \\
\text { covid }\end{array}$ & $\begin{array}{l}\text { Frekuensi } \\
\text { (n) }\end{array}$ & $\begin{array}{c}\text { Persentase } \\
\text { (\%) }\end{array}$ \\
\hline Tidak & 150 & 98,7 \\
\hline Ya & 2 & 1,3 \\
\hline TOTAL & 152 & 100,0 \\
\hline
\end{tabular}


Jurnal Untuk Masyarakat Sehat (JUKMAS)

Berdasarkan tabel 3. di atas menggambarkan bahwa dari 152 responden berdasarkan positif/diduga covid. Ada sebanyak 150 orang $(98,7 \%)$ yang tidak positif/tidak diduga covid dan sebanyak 2 orang (1,3\%) yang positif/diduga covid.

Tabel 4. Distribusi frekuensi pernah

kontak langsung dengan penderita

covid

\begin{tabular}{ccc}
\hline Kontak & Frekuensi & Persentase \\
langsung & (n) & $(\%)$
\end{tabular}

\begin{tabular}{lccc}
\hline $\begin{array}{c}\text { Tidak kontak } \\
\text { langsung } \\
\text { Ya kontak } \\
\text { langsung }\end{array}$ & 136 & 89,5 \\
\hline TOTAL & $\mathbf{1 5 2}$ & $\mathbf{1 0 0 , 0}$ \\
\hline \multicolumn{1}{c}{ Berdasarkan tabel 4.} & di & atas \\
menggambarkan & bahwa & dari & 152 \\
responden, ibu menyusui & yang tidak \\
kontak langsung dengan orang terinfeksi \\
virus covid ada sebanyak 136 orang \\
(89,5\%). Dan yang kontak langsung ada \\
sebanyak 16 orang (10,5\%).
\end{tabular}

Tabel 5. Hasil Analisis Bivariat perilaku hidup bersih dan sehat pada masa pandemi covid 19

\begin{tabular}{|c|c|c|c|c|c|c|c|c|}
\hline \multirow{3}{*}{$\begin{array}{c}\text { Variabel } \\
\text { Independent }\end{array}$} & \multicolumn{4}{|c|}{ Perilaku Hidup Bersih dan Sehat } & & & \multirow{3}{*}{$\mathbf{P}_{\text {Value }}$} & \multirow{3}{*}{$\begin{array}{c}\text { OR }(95 \% \\
\text { Cl) }\end{array}$} \\
\hline & \multicolumn{2}{|c|}{ Tidak } & \multicolumn{2}{|c|}{ Ya } & \multicolumn{2}{|c|}{ Total } & & \\
\hline & $\mathbf{n}$ & $\%$ & $\mathrm{n}$ & $\%$ & $\mathbf{N}$ & $\%$ & & \\
\hline \multicolumn{9}{|l|}{ Gejala } \\
\hline Tidak ada gejala & 81 & 62,8 & 48 & 37,2 & 129 & 100,0 & \multirow{2}{*}{0,058} & 2,625 \\
\hline Ada gejala & 9 & 39,1 & 14 & 60,9 & 23 & 100,0 & & $(1,056-$ \\
\hline Jumlah & 90 & 59,2 & 62 & 40,8 & 152 & 100,0 & & $6,523)$ \\
\hline
\end{tabular}

\section{Positif/}

diduga Covid

$\begin{array}{ccccccccc}\text { Tidak } & 88 & 58,7 & 62 & 41,3 & 150 & 100,0 & 0,349 & 0,587 \\ \text { Ya } & 2 & 100 & 0 & 0 & 2 & 100,0 & & (0,513- \\ \text { Jumlah } & 90 & 59,2 & 62 & 40,8 & 152 & 100,0 & & 0,671)\end{array}$

\section{Kontak}

Langsung

Tidak

$78 \quad 57,4 \quad 58$

$42,6 \quad 136 \quad 100,0$

0,276

0,448 


$\begin{array}{lllllll}\text { Ya } & 12 & 75,0 & 4 & 25,0 & 16 & 100,0\end{array}$

\begin{tabular}{cccccccc} 
Jumlah & 90 & 59,2 & 62 & 40,8 & 152 & 100,0 & $1,461)$ \\
\hline & & diduga covid sebesar 62 orang (41,3\%) dan
\end{tabular}

Berdasarkan tabel 5 . hasil analisis hubungan antara gejala sakit pada ibu menyusui dengan perilaku hidup bersih dan sehat (PHBS) didapatkan bahwa ada sebanyak 48 orang $(37,2 \%)$ ibu yang tidak memiliki gejala sakit berperilaku hidup bersih dan sehat. Sedangkan ibu yang memiliki gejala sakit, ada 14 orang $(60,9 \%)$ yang berperilaku hidup bersih dan sehat. Hasil uji statistik diperoleh nilai $P_{\text {value }}=0,058$ maka dapat disimpulkan bahwa tidak ada hubungan gejala sakit dengan perilaku hidup bersih dan sehat

Menurut Elizabeth Yohmi, Ketua SATGAS ASI IDAI dalam Praktik menyusui di masa pandemo covid 19. Menyusui melindungi bayi baru lahir dari sakit dan juga membantu melindungi mereka selama masa bayi dan kanak. Seperti semua kasus COVID 19, ibu yang terkonfirmasi atau dicurigai, ibu dengan gejala apapun yang sedang menyusui atau melakukan kontak kulit ke kulit harus melakukan tindakan pencegahan [10].

Berdasarkan hasil penelitian di atas maka peneliti berasumsi bahwa perilaku hidup bersih sehat bisa ditanamkan dan diajarkan dari kecil mulai dari keluarga inti. Kesadaran dan kebiasaan menjadi yang utama daripada kondisi responden baik ketika sakit ataupun tidak.

Berdasarkan tabel 5, ibu yang berperilaku hidup bersih dan sehat dan tidak positif/tidak tidak ada (0\%) responden yang memiliki perilaku hidup bersih dan sehat dan terinfeksi/diduga mengalami covid. Hasil uji statistic didapatkan nilai $P_{\text {value }}=0,349$ maka dapat disimpulkan tidak ada hubungan yang bermakna antara responden yang positif/diduga covid dengan perilaku hidup bersih dan sehat.

Untuk ibu dengan dugaan atau infeksi SARS-CoV-2 yang bayinya negatif atau dengan hasil tes yang tertunda, pengambilan keputusan bersama antara penyedia dan ibu merupakan komponen penting dalam memilih nutrisi yang optimal untuk bayi [25]. Prinsip panduan utamanya adalah manfaat menyusui bagi ibu dan bayi, risiko penularan dari ibu ke neonatus, dan perkiraan keparahan penyakit yang relatif ringan pada neonatus. Tingkat keparahan infeksi ibu dan kemampuannya untuk menyusui secara langsung mempengaruhi proses pengambilan keputusan ini, karena tingkat keparahan penyakit berkaitan dengan kemampuan ibu untuk memberi makan dan merawat bayinya[26]

Ada 4 pesan utama bagi lbu yang positif/diduga Covid dan khawatir menularkan virus ke bayinya. Sampai saat ini belum ada bukti yang menunjukkan bahwa virus Covid 19 dapat ditularkan melalui ASI. Nenonatus dan bayi memiliki risiko rendah terkena infeksi 
Covid 19. Di antara kasus yang ada pada anak kecil, kebanyakan dari mereka hanya mengalami penyakit ringan atau tanpa gejala. Menyusui dan skin to skin contact dapat meminimalisir angka kematian bayi juga bermanfaat untuk tumbuh kembang seumur hidupnya dan tidak dapat terulangi lagi. Menyusui juga bermanfaat utk mencegah terjadinya kanker payudara dan kanker ovarium pada ibu. Banyaknya manfaat menyusui jauh melebihi potensi risiko ketularan virus Covid 19 [6].

Selain itu, dilihat dari manfaat ASI secara keseluruhan, manfaat nutrisi, imunologis, dan perkembangan ASI untuk bayi baru lahir dalam waktu jangka pendek maupun jangka panjang, pemberian ASI tidak boleh ditahan terhadap bayi. Perawatan ibu, keparahan infeksi ibu dan ketersediaan sumber daya dapat mempengaruhi keputusan menyusui, peran pengambilan keputusan bersama tentang menyusui antara ibu dan dokter. Kami sangat menganjurkan pemberian ASI langsung dengan kewaspadaan higienis yang sesuai kecuali kondisi kesehatan ibu atau bayi mengharuskan pemisahan [4].

Covid 19 tidak terdeteksi pada Air Susu Ibu (ASI). Namun fokus utama kekhawatiran adalah apakah wanita yg terinfeksi dapat menularkan virus melalui tetesan pernafasan selama menyusui [11]. Beberapa badan kesehatan internasional dan sosial medis termasuk WHO mendukung pemberian ASI langsung dengan kewaspadaan higienis dan merekomendasikan pemisahan ibu dan neonatus hanya di situasi kondisi kesehatan ibu yang buruk atau kebutuhan untuk memberikan terapi kepada bayi baru lahir. Sebaliknya, badan-badan AS, termasuk Pusat Pengendalian dan Pencegahan Penyakit (CDC) dan American Academy of Pediatrics (AAP), telah mengambil pendekatan yang lebih konservatif terhadap potensi penularan dari ibu ke anak. Pedoman yang direvisi yang diterbitkan oleh AAP kemudian mempromosikan baik menyusui langsung dan penggunaan ASI perah. CDC mengakui pentingnya kontak ibu-bayi dan pengambilan keputusan bersama antara keluarga dan dokter tetapi tidak memberikan panduan yang jelas tentang menyusui [12][13] [14] [15][16].

AAP merekomendasikan pemisahan sementara dari ibu-bayi dan pemberian ASI perah daripada pemberian ASI langsung untuk mengurangi risiko infeksi bayi pasca kelahiran dari sekresi pernapasan ibu [17]. Di pusat medis AS mengikuti panduan CDC dan AAP, kami melihat pemisahan rutin bayi dari ibu dengan kemungkinan atau dugaan infeksi SARS-CoV-2. Dalam situasi ini, hanya sejumlah kecil ibu-bayi yang meminta menyusui langsung. Pemisahan antara ibu dan bayi memiliki berpotensi berbahaya seperti stres, produksi ASI berkurang, pemberian ASI yang buruk dan hilangnya manfaat perawatan kulitke-kulit meningkatkan risiko ketidakstabilan bayi dan potensi kebutuhan akan perawatan 
unit perawatan intensif neonatal (NICU) sebagai akibat dari pemisahan bayi [18].

Ibu yang diduga atau terkonfirmasi Covid 19 , ada baiknya menggunakan masker medis selama menyusui. Dada ibu perlu dibasuh apabila terkena percikan ludah saat batuk. Payudara tidak perlu dibilas setiap kali akan menyusui [6].

Kontak kulit ibu dan bayi baru lahir memiliki banyak manfaat, termasuk peningkatan ikatan ibu dan bayi, pengaturan glukosa darah bayi, dan stabilisasi suhu bayi baru lahir. Selama pandemi Covid 19, beberapa unit bersalin telah mencegah kontak kulit ibu dan bayi, karena kekhawatiran akan pajanan / infeksi pada bayi. Beberapa peneliti melaporkan tidak ada data yang mendukung peningkatan resiko bayi baru lahir terpajan virus covid 19 setelah skin to skin contact dan biasanya keuntungan kontak kulit lebih besar daripada risiko teoretisnya. Editorial merekomendasikan bahwa, selama langkah-langkah pencegahan infeksi diikuti, satu-satunya ibu dengan COVID-19 yang tidak boleh mempraktikkan skin to skin contact adalah mereka dengan kasus yang begitu parah sehingga mereka secara fisik tidak dapat melakukannya. Hal ini sejalan dengan WHO [19].

Berdasarkan hasil penelitian diatas maka peneliti berasumsi bahwa tidak ada hubungan yang bermakna antara positif/diduga covid dengan PHBS adalah karena hasil yang cenderung homogen. Maksudnya hasilnya hampir semua ibu tidak positif/tidak diduga covid. Selain itu, adanya kemungkinan responden yang OTG atau orang tanpa gejala sehingga dirinya tidak mengetahui terinfeksi virus covid 19 ataupun tidak.

Berdasarkan Tabel 5 bahwa ibu menyusui yang berperilaku hidup bersih dan sehat secara baik dan tidak kontak langsung dengan orang yang terinfeksi covid sebanyak 58 orang (42,6\%). Sedangkan ibu menyusui yang berPHBS secara baik dan kontak langsung sebesar 4 orang (25\%). Hasil uji statistik diperoleh nilai $P_{\text {value }}=0,276$ maka tidak ada hubungan yang signifikan antara kontak langsung dengan perilaku hidup bersih dan sehat.

Berdasarkan hasil penelitian, peneliti pun berasumsi bahwa tidak adanya hubungan antara kontak langsung dengan perilaku hidup bersih dan sehat adalah karena dalam kondisi pandemi seperti ini setiap individu memiliki sikap mawas diri. Setiap individu lebih memperhatikan kesehatannya seperti mencuci tangan, memakai masker, memakan makanan yang bergizi untuk menjaga daya tahan tubuhnya dari serangan virus Covid 19. Dan itu terus menerus dilakukan baik ketika kontak langsung maupun tidak. Lagi pula memang banyak orang tanpa gejala sehingga berhati hati tetap dijalani.

Bayi yang terkonfirmasi positif Covid 19 baru diketahui setelah 30 jam pasca melahirkan dan semuanya dari ibu yang positif [11]. Data tentang Covid 19 pada 
neonatus masih sangat terbatas karena penularan pada neonatus masih jarang. Sekalipun ada biasanya tidak memiliki gejala atau ringan saja. [20]. Anak yang terpapar Covid 19 dan rentan seperti memiliki riwayat penyakit asma berat, perlu pemantauan khusus [21]

Penelitian di Rumah Sakit Umum di Queens, New York, USA. Sebanyak 118 kelahiran, 45 neonatus (38\%) dilahirkan dari ibu yang positif covid 19. Mayoritas sebanyak $27,6 \%$ ibu tidak memiliki gejala. Ada sebanyak 7 neonatus (16\%) dirawat di ICU neonatal (NICU) karena prematur dan dugaan sepsis. Tidak ada satu pun dari 45 bayi baru lahir yang membutuhkan perawatan NICU karena gejala terkait Covid. Mereka yang lahir dari ibu positif Covid, 73\% (33/45) tinggal bersama ibunya, termasuk 31 bayi (94\%) yang disusui dalam waktu satu jam setelah lahir. Tiga bayi yang baru lahir dinyatakan positif SARS Covid dan mereka dipantau di NICU. Peneliti menyimpulkan bahwa tidak ada hasil neonatal yang dirugikan dengan perawatan kulit ke kulit, rawat inap, atau menyusui pada bayi baru lahir oleh ibu yang positif covid [22].

Penelitian terbaru mengatakan bahwa pemberian ASI jauh lebih penting ketika masa pandemi untuk meningkatkkan kekebalan tubuh anak sekalipun anak tersebut terpapar virus Covid 19. Yang penting ibu tetap menerapkan protokol kesehatan yaitu mencuci tangan dan menggunakan masker saat menyusui [20]. Anak memiliki beberapa fase dalam kehidupannya. Pertama, fase oral. Dimana bayi senang memasukkan sesuatu ke dalam mulutnya, termasuk menyusu atau menghisap walaupun tidak lapar. Kedua, fase phalik yaitu balita tertarik dengan orangtua lawan jenis. Ketiga, fase latens yaitu terkait interaksi sosial. Keempat, fase genital, anak tertarik pada lawan jenis. Keempat fase ini anak mulai diajarkan mencuci tangan dan pakai masker.Pada anak anak, edukasi bisa dilakukan sambil bermain dan bernyanyi[23].

Bagi ibu menyusui yang membutuhkan bantuan praktis dari konselor menyusui atupun tenaga kesehatan namun terbatas akses bisa memanfaatkan penggunaan teknologi informasi dalam rangka pencegahan COVID-19 seperti yang disampaikan melalui Peraturan Menteri Kesehatan Nomor 20 Tahun 2019 tentang Penyelenggaraan Pelayanan Telemedicine Antar Fasilitas Pelayanan Kesehatan dan surat Edaran Nomor HK.02.01/MENKES/303/2020 tentang Penyelenggaraan pelayanan kesehatan melalui pemanfaatan teknologi informasi komunikasi guna pencegahan penyebaran COVID-19 [24] [15].

\section{A. SIMPULAN DAN SARAN}

\section{Simpulan}

Hasil dari penelitian ini membuktikan bahwa tidak ada hubungan yang signifikan antara gejala sakit, positif/diduga covid dan kontak langsung dengan orang yang terinfeksi covid 19 dengan perilaku hidup 
bersih dan sehat terkait menyusui. Saran dari penelitian ini adalah perlu adanya edukasi bahwa ibu yang memiliki gejala sakit, positif atau diduga terinfeksi Covid 19 harus tetap menyusui bayinya dengan menerapkan PHBS. Apalagi sampai saat ini belum ada bukti kuat yang menunjukkan penularan SARS-CoV-2 dari ibu ke bayi melalui jalur vertikal atau ASI PHBS yang dimaksud terkait menyusui yaitu Pertama, mencuci tangan dengan sabun dan air mengalir atau handsanitizer sebelum memegang bayi. Kedua, menggunakan masker medis saat menyusui. Penting sekali untuk mengganti masker segera setelah masker terasa lembab. Ketiga, tutup mulut dengan tisu ketika batuk atau bersin dan langsung mencuci tangan dengan sabun dan air mengalir. Keempat, mendesinfektan seluruh permukaan ruangan secara teratur. Proses menyusui ibu ke bayi tetap harus dilakukan untuk meningkatkan kelangsungan hidup bayi baru lahir, kesehatan dan perkembangan bayi dalam waktu dekat dan jangka panjang.

\section{Saran}

1. Perlu adanya edukasi bahwa ibu menyusui yang memiliki gejala sakit seperti flu, batuk dan demam tetap harus menyusui bayinya dengan menerapkan protokol kesehatan seperti mencuci tangan dengan sabun dan air mengalir atau handsanitier sebelum menyusui, menggunakan masker apabila ibu batuk dan flu.

2. Ibu menyusui yang sakit parah dan tidak memungkinkan menyusui langsung, penting diedukasi untuk memberikan ASI perah kepada bayinya, termasuk mengedukasi cara pemberian, cara penyimpanan dan cara memerah tentunya.

3. Perlu adanya penelitian lain tentang ibu menyusui pada masa covid $19 \mathrm{ini}$ di lokasi yang berbeda seperti langsung di Rumah sakit atau di daerah lain yang memfokuskan pada zona merah sehingga hasil penelitian heterogen

\section{DAFTAR PUSTAKA}

[1] Fikawati S. Gizi Ibu dan Bayi. 1st ed. Depok: Rajawali Pers, 2018.

[2] UNICEF. Menyusui pada masa wabah virus corona (COVID-19), https://www.unicef.org/indonesia/id/s tories/menyusui-pada-masa-wabahvirus-corona-covid-19 (2020).

[3] World Health Organization WHO. WHO Director-General's opening remarks at the media briefing on COVID-19 - 11 March 2020, https://www.who.int/directorgeneral/speeches/detail/who-directorgeneral-s-opening-remarks-at-themedia-briefing-on-covid-19---11- 
march-2020 (2020).

[4] Cheema R, Partridge E, Kair MPHLR, et al. Protecting Breastfeeding during the COVID-19 Pandemic. 95817.

[5] Suriastini, Wayan at all. Research Brief PEMBERIAN ASI DAN POLA MAKAN

BALITA SAAT PANDEMI COVID19: SAATNYA AKTIFKAN PERUBAHAN PERILAKU PEMBERIAN ASI DAN INTERVENSI. 2020.

[6] World Health Organization WHO. FREQUENTLY ASKED QUESTIONS : Breastfeeding and COVID-19 For health care workers. 2020, https://reliefweb.int/report/world/fre quently-asked-questionsbreastfeeding-and-covid-19-healthcare-workers-28-april-2020 (2020).

[7] Pambudi W. Webinar GIZI BERSERI "Tetap Menyusui di Masa Pandemi COVID 19". 2020.

[8] Dirjen P2P Kemenkes RI. Pedoman Pencegahan Pengendalian Covid 19. 4th ed. 2020.

[9] Hidayat T. Pentingnya Perilaku Hidup Bersih dan Sehat. Program Kota Tanpa Kumuh (KOTAKU)., http://kotaku.pu.go.id:8081/wartaarsi pdetil.asp ? mid $=8599 \&$ catid $=2 \&$ ) (2009).

[10] Lawi GFK. ASI Masih Diyakini Bebas dari Penularan Virus Corona, https://lifestyle.bisnis.com/read/2020 0815/236/1279587/asi-masih-diyakini- bebas-dari-penularan-virus-corona (2020).

[11] Chen H, Guo J, Wang C, Luo F, Yu X, Zhang W et al. Clinical characteristics and intrauterine vertical transmission potential of COVID-19 infection in nine pregnant women: A retrospective review of medical records. J Dairy Sci 2020; 6736: 1-7.

[12] World Health Organization WHO. Breastfeeding advice during the COVID-19 outbreak, https://www.emro.who.int/nutrition/n ews/breastfeeding-advice-during-thecovid-19-outbreak.html (2020).

[13] Friday P. Coronavirus ( COVID-19) Infection in Pregnancy. 2021; 1-98.

[14] Riccardo Davanzo1, 2, MD PGM, Sandri4 MF, MD;, et al. Breastfeeding and Coronavirus Disease-2019. Ad interim indications of the Italian Society of Neonatology endorsed by the Union of European Neonatal \& Perinatal Societies. 2019; 0-1.

[15] Aprillia, Yuna Trisuci, Asyifa Robiatul Adawiyah SA. Analisis Penggunaan Alat Kontrasepsi Sebelum Dan Saat Pandemi Covid-19 1. J Untuk Masy Sehat 2020; 4: 190-200.

[16] Coronavirus Disease 2019 (CDC). Considerations for Inpatient Obstetric Healthcare Settings, https://www.cdc.gov/coronavirus/201 9-ncov/hcp/inpatient-obstetric- 
healthcare-guidance.html (2020).

[17] Anika Kumar, MD, FHM F.

Management of infants born to

mothers with COVID-19. the

Hospitalist, https://www.the-

hospitalist.org/hospitalist/article/2211

57/pediatrics/management-infants-

born-mothers-covid-19 (2020).

[18] Stuebe A. Should Infants Be Separated from Mothers with COVID-19? First, Do No Harm. Breastfeed Med 2020; 15: 351-352.

[19] Davanzo R, Merewood A, Manzoni P. Skin-to-Skin Contact at Birth in the COVID-19 Era : In Need of Help ! 2020; 1: 8-11.

[20] Procianoy RS, Silveira RC, Manzoni P SG. Neonatal COVID-19: Little evidence and the need for more information. $J$ Pediatr (Rio J) 2020; xx: 1-8.

[21] Sinha IP, Harwood R, Semple MG, Hawcutt DB, Thursfield R, Narayan O et al. COVID-19 infection in children. Lancet Respir 2020; 20: 1-2.
[22] Patil UP, Maru S, Krishnan P, et al. Newborns of COVID-19 mothers : short-term outcomes of colocating and breastfeeding from the pandemic's epicenter. J Perinatol 2020; 14551458.

[23] Anung Ahadi Pradana, Casman N. f. J Kebijak Kesehat Indones JKKI 2020; 09: 61-67.

[24] dr. Bambang Wibowo, Sp.OG (K) M. PEMANFAATAN TEKNOLOGI INFORMASI DALAM RANGKA PENCEGAHAN PENYEBARAN COVID 19. 2020.

[25] Chandrasekharan $P$, Vento $M$, Trevisanuto D, et al. Neonatal resuscitation and postresuscitation care of infants born to moth- ers with suspected or confirmed SARS-CoV-2 infection. Am J Perinatol 2020

[26] Liu Y, Yan LM, Wan L, et al. Viral dynamics in mild and severe cases of COVID-19. Lancet Infect Dis 2020;20(06):656-657 